\title{
HOW NUMBER OF NORMAL BREATHING PER MINUTES INFLUENCE ON THE LIKELINESS OF PINEAPPLE
}

Muhammad Imran Qadir \& AsmaRasheed*

Institute of Molecular Biology and Biotechnology, BahauddinZakariya University, Multan,

Pakistan

\begin{abstract}
The object of the instantaneous study was to combine relations of number of normal breathing per minutes with likeness of pineapple. One hundred and thirty students take parts in this study. A survey was provide them, and asked about their likes pineapple and number of normal breathing per minutes. Present research shows that students like to eat pineapple have number of normal breathing per minutes other then do not like to eat pineapple.
\end{abstract}

Keywords: normal breathing per minutes, pineapple likeness 


\section{INTRODUCTION}

A person amount of normal breaths take during one minute time period while at rest. Very essential respiratory rate predicating serious medical events. Increase respiration rate with illness fever and other medical conditions. Per minute person rest range 12 to 16. Per minute typical person breaths at a rate 12 to 20. Abnormal breathing can become very difficult.effects the respiratory situation nerves muscles organ. Older patients' normal respiratory rates 12 to 18 per minute. Natural breathing fistbreathing skill. Good breathing rate while resting 12 to 20 per minute. High breathing rate is up 44 per minute. Rapid breathing can causes asthma pneumonia anxiety heart failure lung diseases. Serious breathing and shortness of breath can causes high blood pressure cardiovascular health issue cholesterol level is high can cause cancer of lungs chest burning can cause asthma inflammation of bronchial tubes. Asthma attack difficult to breathe human and heavy labored breathing.

Pineapple inexpensively significant plant. Pineapple decrease excessive coagulation of the blood. Pineapple delicious healthy tropical fruit. Pineapple fitness fitness speeding up recovery surgery. Pineapple contains crabs manganese copper thiamin iron potassium calcium zing phosphorus. Pineapple is important healthy growth and development essential for healthy immune system. Pineapple breakdown of amino acid.Objective of the instantaneous learning was to associate relations of number of normal breathing per minute with pineapple likeness.

\section{MATERIALS AND METHOD}

One hundred and thirty learners joined in this study. Inquiry was providing them in which they were asked about their likeliness of pineapple and number of normal breathing per minute. All the students counting number of normal breathing per minute.

\section{Project}

Survey was intended about number of normal breathing per minute and pineapple likeliness

\section{Statistical study}

Fulfilled statistical study was done by Microsoft excel.

\section{DISCUSSION}

Subjects with number of normal breathing per minute 21.01 \pm 7.181 like pineapple While students number of normal breathing per minute $21.4 \pm 3.99$ do not like pineapple. 
Table number 1: association number of normal breathing per minute mean pulls stranded deviations.

\begin{tabular}{|l|l|l|l|}
\hline $\begin{array}{l}\text { Number of normal } \\
\text { breathing per } \\
\text { minute }\end{array}$ & Pineapple likeness & $\begin{array}{l}\text { Pineapple } \\
\text { dislikeness }\end{array}$ & P-Value \\
\hline & & & \\
& $21.01 \pm 7.181$ & $21.4 \pm 3.99$ & 0.7 \\
\hline
\end{tabular}

\section{Conclusion}

Present research show that the students who like to eat pineapple have more number of normal breathing per minute and the other do not like to eat pineapple.

\section{REFERENCE}

1. Qadir MI, Malik SA (2010) Comparison of alterations in red blood cell count and alterations in hemoglobin concentration in patients suffering from rectal carcinoma undergoing 5-fluorouracil and folic acid therapy. Pharmacologyonline, NI 3: 240-243.

2. Qadir Ml, Noor A (2018) Anemias. Rare \& Uncommon Diseases. Cambridge Scholars

Publishing. Newcastle, England. ISBN: 978-15275-1807-0.

3. Qadir Ml, Javid A (2018) Awareness about Crohn's Disease in biotechnology students. GloAdv Res J Med Medical Sci, 7(3):062-064.

4. Qadir MI, Saleem A (2018) Awareness about ischemic heart disease in university biotechnology students. GloAdv Res J Med Medical Sci, 7(3): 059-061.

5. Qadir Ml, Ishfaq S (2018) Awareness about hypertension in biology students. Int J Mod Pharma Res, 7(2): 08-10.

6. Qadir Ml, Mehwish (2018) Awareness about psoriasis disease. Int J Mod Pharma Res, 7(2): 17-18.

7. Qadir MI, Shahzad R (2018) Awareness about obesity in postgraduate students of biotechnology. Int J Mod Pharma Res, 7(2): 14-16.

8. Qadir MI, Rizvi M (2018) Awareness about thalassemia in post graduate students. MOJ Lymphology\&Phlebology, 2(1): 14-16.

9. Qadir MI, Ghalia BA (2018) Awareness survey about colorectal cancer in students of M. Phil Biotechnology at 
BahauddinZakariya University, Multan, Pakistan. Nov Appro in Can Study, 1(3): NACS.000514.2018.

10. Qadir MI, Saba G (2018) Awareness about intestinal cancer in university student. Nov Appro in Can Study, 1(3): NACS.000515.2018. 